\title{
CZŁOWIECZEŃSTWO, SPRAWCZOŚĆ I TROSKA TRANSCENDENTNA ${ }^{1}$
}

\author{
Humanity, agency and transcendent concern
}

\begin{abstract}
Streszczenie
Celem artykułu jest rozważenie zasadności włączenia troski transcendentnej do zestawu trosk podstawowych w życiu człowieka, tak jak je rozumie Margaret S. Archer. Omówiono rozumienie tej troski w tekstach brytyjskiej socjolog, a następnie scharakteryzowano proponowane przez autora poszerzone jej rozumienie. Znaczenie troski transcendentnej dla człowieka i życia społecznego przedstawiono krótko poprzez ukazanie jej wpływu na sprawczość człowieka. Opisano także relacje między troskami ze szczególnym uwzględnieniem miejsca troski transcendentnej. Poczynione rozważania prowadzą do ostatecznego przyznania tej trosce miejsca wśród podstawowych trosk człowieka, mających charakter uniwersalny.
\end{abstract}

Słowa kluczowe: socjologia humanistyczna, troski podstawowe, troska transcendentna, transcendencja, Margaret S. Archer

\begin{abstract}
The main purpose of the article is to consider the merits of including transcendent concern in the set of ultimate concerns in human life, as they are understood by Margaret S. Archer. First, it is discussed the understanding of this concern presented in Archer's works, and then characterized the broader understanding proposed by its author. Its significance regarding human and social life is presented briefly by showing its influence on human agency. Finally, the relationships between concerns are discussed, with particular emphasis on the place of transcendent concern. The conclusions drawn lead to a final acknowledgment of the place of this concern amongst other fundamental human concerns of a universal nature.
\end{abstract}

Keywords: humanistic sociology, ultimate concerns, transcendent concern, transcendence, Margaret S. Archer

\section{Wprowadzenie}

Rozważania na temat człowieczeństwa w kontekście teorii socjologicznych kierują w sposób szczególny na różne teorie podmiotowości rozwinięte w nurcie socjologii humanistycznej. Jednym z pionierów tego nurtu był Georg Simmel, którego teksty inspirują do dziś wielu badaczy życia społecznego. Późniejsza faza jego intelektualnego rozwoju nazywana jest „fazą filozofii życia” czy nawet można by ją określić fazą religijną. Religia bowiem i odniesienie do wymiaru transcendentnego zajmuje istotne miejsce w jego myśli, choć stosunkowo rzadko jest on postrzegany przez pryzmat dzieł z tego zakresu (zob. Motak 2013: 22-33; zwłaszcza Simmel 2007a).

W nurt socjologii humanistycznej wpisuje się podejście Margaret $S$. Archer wraz z jej koncepcją podmiotu, jego podstawowych trosk i sprawczości, która według niej ma pierwotny charakter wobec wszelkich struktur społecznych. Człowiek „niesie w sobie” potencjał, który, w kształtowaniu rzeczywistości społecznej, jest

1 Angielska wersja artykułu, przyjęta do druku, ukaże się równolegle w czasopiśmie „Seminare” 2019, nr 4. 
nieredukowalny do żadnych struktur, niemożliwy do zastąpienia w pełni przez nie. $Z$ drugiej strony ten potencjał może być rozwinięty i pełniej zrealizowany wówczas, gdy napotka odpowiednie, sprzyjające struktury.

Potencjał ten określany jest przez socjologów w rozmaity sposób. Archer często używa zwrotu „wartości i siły”, Piotr Sztompka zaś mówi o „wrodzonych tendencjach, zarodkach i zalążkach przyszłości, zdolnościach, "mocach"" (2005: 202). Człowiek jest zdolny do autorefleksji, do działania niezdeterminowanego, do celowego kierowania własnym rozwojem i relacji z innymi ludźmi. Z tym szczególnym potencjałem tkwiącym w człowieku związana jest zdolność do działania innowacyjnego, do kreatywności, która nie tylko udoskonala istniejące struktury, lecz także prowadzi do powstawania nowych, coraz bardziej dostosowanych do potrzeb ludzi i zmieniającego się otoczenia. Działalność podmiotów ludzkich związana jest nierozłącznie z funkcjonowaniem struktur społecznych, co wynika z relacyjnej natury człowieka: relacyjność jest istotnym wymiarem bytowania człowieka, zakotwiczonym w jego naturalnym potencjale (Donati, Archer 2015).

Dzięki swej refleksyjności człowiek rozpoznaje istotne wymiary swego bytowania, związane z jego podstawowymi potrzebami czy, jak określa to Archer, podstawowymi troskami. Troski te, tzn. to, o co człowiek się troszczy, określają według niej to, kim człowiek jest, co niesie w sobie jego człowieczeństwo. Celem tego przedłożenia jest przedyskutowanie uzupełnienia zestawu wyróżnionych przez nią podstawowych trzech trosk o troskę transcendentną.

\section{Margaret S. Archer o trosce transcendentnej}

Wymieniając i omawiając podstawowe troski człowieka, brytyjska socjolog nie podaje wprost troski transcendentnej. W swych najbardziej znanych dziełach, zwłaszcza w podstawowej dla tych rozważań pozycji Człowieczeństwo. Problem sprawstwa (Being human) (2013), wymienia i omawia troskę naturalną, dotyczącą ochrony zdrowia i stosunku do otoczenia, troskę praktyczną, związaną z kompetencjami i osiągnięciami performatywnymi, oraz troskę społeczną, odnoszącą się do poczucia własnej wartości w relacji do innych osób.

Jednakże w pozycji, która powstała już po wielu podstawowych dla jej teorii dziełach, a której jest współautorką, pt. Transcendence. Critical realism and God (Archer, Collier, Porpora 2004a), wskazuje wyraźnie na istotne czy wręcz fundamentalne znacznie tego wymiaru życia dla wielu ludzi. Problem stanowi to, czy można ten wymiar uznać za charakteryzujący człowieka jako takiego, tzn. każdego człowieka, jako istotny wymiar człowieczeństwa. Zanim ustosunkujemy się do tej wątpliwości, najpierw należy ustalić, co na temat znaczenia tego wymiaru i jego powszechności mówi Archer.

Pierwsza uwaga, o charakterze metodologicznym, poczyniona przez wszystkich autorów Transcendence, to oparte na prostej logice przekonanie o potrzebie uwzględnienia rozważań na temat Transcendencji w naukach społecznych na równi z paradygmatami wykluczającymi taką możliwość. Znaczenie tej rzeczywistości określanej często jako Bóg jest łatwe do zaobserwowania w przypadku życia większości ludzi na świecie, w ich postawach i działaniach. Ponieważ to człowiek jest podstawowym inicjatorem zmian społecznych, to w perspektywie nauk społecznych ważne jest uwzględnienie wszystkiego, co go stanowi, kształtuje, co ma na niego wpływ.

Kolejna kwestia, która wynika z analizy Archer dotyczącej życia mistyków katolickich i ich pism, ich relacji z innymi ludźmi oraz funkcjonowania w strukturach społecznych, to odniesienie do rzeczywistości transcendentnej jako realnie istniejącej i oddziałującej na ich życie, postawy, sposób działania, a poprzez to na rzeczywistość ich otaczającą. Analiza ta prowadziła do uznania rzeczywistego wpływu Transcendencji na rzeczywistość społeczną poprzez osoby przeżywające szczególną relację z Bogiem. W tekstach brytyjskiej socjolog znaleźć można również próby wyjaśnienia, dlaczego nie wszyscy poznają tę rzeczywistość i jej doświadczają.

Po trzecie, co również wynika ze studium Archer, relacja do Boga, a tym samym troska transcendentna jest dla wielu osób nie tylko ważna, ale wręcz najważniejsza, kształtująca całe życie człowieka i podporządkowująca wszystkie inne, w tym podstawowe troski. Prowadzi to w prosty sposób do stwierdzenia, że opis człowieka, jego człowieczeństwa bez uwzględnienia odniesienia do Transcendencji, bez uwzględnienia troski transcendentnej staje się wówczas nie tylko niepełny, ale wprost ułomny. Archer wiąże rzeczywistość 
transcendentną - Boga z doskonałą bezwarunkową miłością. Miłość, która jest czymś podstawowym także w relacjach międzyludzkich, ma w nich jednak zawsze mniej lub bardziej niedoskonały charakter ze względu na ograniczoność i ułomność człowieka. Jedynie Byt, którego samo istnienie i doskonałość nie zależy od nikogo i którego istotą jest miłość, daje człowiekowi możliwość pełnej samorealizacji; pozbawienie się relacji z Bogiem oznacza zatem pozbawienie się tej możliwości (zob. zwłaszcza Archer 2004a: 63-81; Archer, Collier, Porpora 2004b: 24-40).

\section{Rozumienie troski transcendentnej}

Prowadząc rozważania na temat troski transcendentnej, należy dookreślić, co rozumiane będzie przez to pojęcie. Najbardziej oczywiste, wynikające z samej nazwy, jest odniesienie do relacji z Transcendencją, najczęściej nazywaną Bogiem. Jak już zostało wspomniane powyżej, a co jest faktem niewymagającym dodatkowych uzasadnień, nie wszyscy wierzą w istnienie osobowego Boga, a nawet jakiejkolwiek rzeczywistości przekraczającej, wychodzącej poza rzeczywistość widzialną.

Pierwszy wymiar troski transcendentnej, prowadzący wiele osób ku Transcendencji i mający charakter powszechny, tzn. dotyczący każdego refleksyjnego podmiotu, stanowi świadome ustosunkowanie się do faktu własnej śmierci i śmierci innych osób. Człowiek stopniowo rozpoznaje swoją kondycję, jej kruchość, niepewność, nabywa świadomości skończoności własnego życia i życia innych ludzi. Pytanie o śmierć i jej naturę jest wpisane w byt każdego człowieka, a od wieków rozważają nad nim różni myśliciele (Pieper 1970). Współcześnie również socjologowie podejmują szerzej zagadnienie umierania, śmierci i żałoby, a nurt ten nazywa się tanatosocjologią (Mariański 2017: 23). Możliwości trwania ludzkiego życia mają swoje naturalne granice, które tylko w niewielkim stopniu można próbować przesunąć. Ponadto egzystencja człowieka w tym świecie wystawia na zagrożenie życie w każdym jego momencie, z powodu wielu różnych czynników. Stanowi to zatem pierwszy problem odniesienia transcendentnego, czegoś, co zupełnie przekracza człowieka i jego możliwości, co niesie niewiadomą (Pieper 1970: 15-18). Doświadczenie to jest wspólne wszystkim ludziom, niezależnie od kultury, religii, czasu. Ustosunkowanie się do tego faktu można odsuwać od siebie, ale on się nie zmienia - jest nieunikniony, tak jak i ostateczna odpowiedź człowieka wobec tej rzeczywistości. Im bardziej człowiek zbliża się do niej w wyniku procesu starzenia się lub choroby, tym bardziej czuje się przymuszany do pochylania się nad nią (Szczepański 1999: 115-135). Współczesne tendencje kulturowe w krajach zachodnich wykazują dążenie do ukrywania faktu śmierci, co wynika z nieumiejętności udzielenia sensownej odpowiedzi wobec niej i swego rodzaju ucieczki przed nią.

Stosunek do śmierci pociąga za sobą z kolei konieczne odniesienie do zagadnienia życia po śmierci (Seibert, Luther 2010): czy jest, czy go nie ma, jaki ma charakter, na ile moje obecne życie rzutuje na nie, co stanie się ze mną po śmierci, czy zachowam swą tożsamość, czy będę miał ciało, jaki będzie miało charakter itd. Człowiek świadomy skończoności swego życia i stający w jego obliczu odkrywa w sobie pragnienie jego kontynuacji, czy wręcz pragnienie życia, które się nie kończy, co wydaje się także wpisane w jego naturę, w jego człowieczeństwo. Nawet samobójcy często nie odrzucają życia w ogóle, ale nie chcą „takiego” życia, tzn. naznaczonego cierpieniem, z którego nie widzą żadnego wyjścia. Wielu z nich zaś ma nadzieję właśnie na coś lepszego po śmierci albo sądzi, że przynajmniej nic gorszego ich nie spotka.

Jednakże odpowiedzi dotyczące życia po śmierci, nawet samego faktu jego istnienia bądź nie, są bardzo różne. Wszystkie główne religie dają swym wyznawcom określoną wizję losu człowieka po śmierci, co należy do istotnych elementów ich doktryn. Są również osoby, które uważają, że nie ma żadnej kontynuacji życia człowieka po jego śmierci, ale osób przekonanych, że człowiek znika zupełnie wraz z momentem swojej śmierci jak obumarłe drzewo, jest stosunkowo niewiele; nawet bowiem osoby nieidentyfikujące się z żadną religią często tworzą sobie własne wyobrażenie życia po śmierci (Bauman 1998: 69-72). Dramat człowieka stającego wobec ograniczonego charakteru swego życia, ale także sposób jego przekraczania oraz skierowanie ku nieśmiertelności ukazywał również w swoich pismach Simmel (2007b: 90-132, 2007c: 15-35).

Podejście do życia po śmierci i jego związku z doczesnym życiem implikuje sposób czy strategię postępowania i zaangażowania w tym życiu. Już od wieków powtarzane są dwa sformułowania wyrażające takie 
podstawowe strategie życiowe²: jedna skoncentrowana na świadomości końca swego życia - memento mori, a druga kieruje na jak najlepsze „użycie” czasu, który człowiek ma do dyspozycji, bez większego przejmowania się problemem jego końca - carpe diem. Szybko również sformułowano strategię, która łączy obie skrajności: carpe diem et memento mori - właściwie i dobrze korzystaj z czasu, jaki ci został dany, pamiętając, że umrzesz. Niezależnie od strategii ustosunkowanie się do życia po śmierci ma istotne znaczenie dla sposobu funkcjonowania i działania człowieka, a w konsekwencji funkcjonowania całego społeczeństwa. Wyrazem tego są przecież całe epoki, w których wizje religijne odgrywały większą bądź mniejszą rolę, w których przeważające strategie życiowe ludzi przekuwane były na konkretne urządzenia społeczne i sposób funkcjonowania społeczeństwa. Pierwsze badania socjologiczne przeprowadzone przez Barneya Glasera i Anselma Straussa (1965), będące podstawą sformułowania przez nich teorii ugruntowanej, dotyczyły wpływu świadomości umierania na interakcje ludzi.

Człowiek, który dąży do kontynuacji swego życia i ma poczucie transcendowania rzeczywistości materialnej, kieruje się ku bytowi, który jest wieczny, niezmienny i który stał się przyczyną jego zaistnienia oraz jego wyjątkowego charakteru pośród stworzenia: ku Bogu, co w filozofii zostało wyrażone w koncepcji homo capax Dei (Wysocki 2015: 140). W tym nakierowaniu i poszukiwaniu troska transcendentna znajduje swój najwyższy wyraz. Odniesienie do śmierci wymaga tylko świadomego zaakceptowania rzeczywistości, która jest nieuchronna. Człowiek nie ma tu żadnego intelektualnego wyboru, miejsca na alternatywę. Kwestia życia po śmierci, która nie wynika z potocznej obserwacji ani nie jest możliwa do udowodnienia metodami dostępnymi dla nauki, daje już szansę różnych odpowiedzi. W przypadku odniesienia do Boga ta wolność opowiedzenia się na tak, nie lub nie wiem (teiści, ateiści, agnostycy) istnieje również, ale dochodzi tu aspekt relacyjności, mojej relacji wobec Niego.

Ustosunkowanie się do istnienia Boga (niezależnie od tego, jak Go pojmujemy) dotyczy również wszystkich świadomych swej kondycji osób. Nawet ci, którzy nie wierzą w życie po śmierci, mogą rozważać, czy uznać Jego istnienie, np. obserwując istniejący świat. Człowiek ukierunkowany jest na dobro i do tego dobra dąży, nie zawsze jednak w sposób właściwy je rozpoznaje (jest to również jedno z założeń realizmu krytycznego). Dla osób wierzących najwyższym dobrem jest Bóg: człowiek zatem spełnia się w relacji z Nim (Archer 2004c: 138-154). Brak chęci pogłębiania osobistej relacji z Bogiem może wynikać bądź z innego Jego obrazu, gdy np. człowiek odczuwa lęk czy wręcz strach przed Bożą wszechmocą, bądź ze słabej wiary człowieka niedoświadczającego pełniej Bożej obecności. W pierwszym wypadku dochodzi do świadomego uciekania przed wszystkim, co może przypominać Boga, w drugim przypadku najczęściej przyjmowana jest pragmatyczna postawa, poprzez którą uznaje się, że „lepszy wróbel w garści niż gołąb na dachu”.

Relacja wobec Boga - Najwyższego Dobra i bezwarunkowej Miłości - jest jednak czymś fundamentalnym dla tak wielu osób, które podporządkowują temu całe swoje życie. Bez jej uwzględnienia zatem nie sposób zrozumieć ich decyzji, postaw, działania i wpływu na otoczenie (Archer 2004b: 92-108, 2004c: 138-154). Bez tego wymiaru mamy do czynienia z istotną redukcją człowieka, bez tego wymiaru wszystkie religie na świecie nie miałyby prawa bytu.

Tabela 1. Cztery podstawowe troski człowieka i ich znaczenie

\begin{tabular}{|l|l|l|l|l|}
\hline $\begin{array}{l}\text { Porządek } \\
\text { rzeczywistości }\end{array}$ & \multicolumn{1}{|c|}{$\begin{array}{c}\text { naturalny } \\
(\mathbf{N})\end{array}$} & \multicolumn{1}{|c|}{$\begin{array}{c}\text { praktyczny } \\
(\mathbf{P})\end{array}$} & \multicolumn{1}{c|}{$\begin{array}{c}\text { społeczny } \\
(\mathbf{S})\end{array}$} & \multicolumn{1}{c|}{$\begin{array}{c}\text { transcendentny } \\
(\mathbf{T})\end{array}$} \\
\hline Znaczenie troski & $\begin{array}{l}\text { Dobrostan } \\
\text { fizyczny i dobro- } \\
\text { stan środowiska }\end{array}$ & $\begin{array}{l}\text { Kompetencje } \\
\text { i osiągnięcia } \\
\text { performatywne }\end{array}$ & $\begin{array}{l}\text { Poczucie własnej wartości } \\
\text { Role i pozycje społeczne } \\
\text { Dbanie o innych }\end{array}$ & $\begin{array}{l}\text { Stosunek do śmierci, } \\
\text { do życia po śmierci, } \\
\text { do Boga }\end{array}$ \\
\hline
\end{tabular}

Źródło: opracowanie własne, w odniesieniu do trzech pierwszych trosk ze szczególnym odniesieniem do Archer (2013).

2 W inny sposób „strategie życia” przedstawia np. Zygmunt Bauman (1998). Zob. także Mariański 2017: 33-36 oraz Szczepański 1995. 
Troskę transcendentną można określić jako dążenie do trwałego dobra przeżywanego w relacji z miłującymi osobami, w tym z istotą najdoskonalszą - Bogiem w obliczu doświadczenia kruchości, skończoności i niedoskonałości obecnej egzystencji. Troska ta w sposób oczywisty rzutuje na sprawstwo i całą działalność człowieka, a także ma istotny wpływ na inne troski podstawowe.

\section{Troska transcendentna a sprawstwo}

Przyjęta strategia życiowa związana z odniesieniem do rzeczywistości transcendentnej wyznacza w znacznym stopniu konkretne podejmowane przez człowieka działania dotyczące własnego życia, a także odnoszące się do funkcjonowania społeczeństwa. Troska transcendentna kształtuje nie tylko poszczególne osoby, ale także, ze względu na ich relacyjność, oddziałuje na innych oraz wpływa na kształtowanie otaczającej człowieka rzeczywistości. Szczególny wymiar znajduje ona w funkcjonowaniu grup religijnych, w których jest ukazywana jako troska porządkująca całe życie człowieka, a zatem i wszystkie pozostałe jego troski. Wynika to z nauczania poszczególnych religii, a więc ma charakter normatywny, który nie zawsze jest w pełni zinternalizowany przez poszczególnych jej wyznawców. Znajduje ona jednak wyraz również w funkcjonowaniu osób w innych grupach i na różnych płaszczyznach - również m.in. w życiu zawodowym, w zaangażowaniu politycznym czy społecznym.

Pierwsze znaczenie sprawcze tej troski wyraża się w kształtowaniu tożsamości osobistej i społecznej człowieka. Kształtowaniu podlega nie tylko ,ja przedmiotowe” (me), lecz także ,ja podmiotowe” (I) (Archer 2015: 99-106). Z tym procesem związane są relacje między poszczególnymi troskami, które zostaną omówione poniżej. Założenie, że nakierowanie na Transcendencję jest wpisane w naturę człowieka (capax Dei), jego potencjalność, oznacza, że człowiek nie rozwija się w pełni, jeśli nie rozwija tego wymiaru swego życia. W tym rozwoju pomocne stają się struktury religijne, które człowiek napotyka w swoim życiu, od małych rodzinnych wspólnot wiary aż po wielkie systemy religijne.

Proces kształtowania się tożsamości człowieka opiera się na ludzkiej potencjalności (człowieczeństwie), która zakłada możliwość jego dynamicznego rozwoju. Człowieczeństwo zatem to nie tylko pierwotny potencjał, lecz także efekt dynamicznego procesu, w którym człowiek przez swoją sprawczość (także rozwijaną) współtworzy własną kondycję, a która dla swej koherencji musi bazować na pierwotnych predyspozycjach w nią wpisanych. W rozwoju tym istotne znaczenie mają także uwarunkowania zewnętrzne i środowisko życia związane przede wszystkim z relacjami z innymi ludźmi. Sprawstwo daje człowiekowi wyjątkowe miejsce pośród innych stworzeń, możliwość oddziaływania na nie, ale też szczególną możliwość oddziaływania na inne osoby.

W zasadzie wszystkie religie, poza kierowaniem ku Transcendencji, wyznaczają swoim członkom zadania performatywne związane z funkcjonowaniem w świecie, tak jak w judaizmie i chrześcijaństwie ogólne zadanie „czyńcie sobie ziemię poddaną” (Rdz 1,28), które zostaje następnie uszczegółowione w innych nakazach. Wskazania te i normy przyjęte przez wierzących miały i mają nadal ważne znaczenie dla kształtowania całej otaczającej ludzkość rzeczywistości. Przekształcanie otaczającej rzeczywistości łączy się również z tworzeniem olbrzymiej kultury materialnej związanej z wyznawaną wiarą - związane są z tym przecież największe zabytki kultury światowej. Wielkie dzieła pisane, malarstwo, rzeźba, architektura i wiele innych aspektów twórczej działalności człowieka mają swoje odniesienie do obecności rzeczywistości transcendentnej w życiu człowieka.

Sprawczość człowieka daje mu możliwość bezpośredniego oddziaływania na innych ludzi również w kwestii troski transcendentnej. Może on starać się kierować innych do Transcendencji, do wiary: dając dobre świadectwo wyznawanej wiary, głosząc prawdy wiary i zachęcając do nawrócenia. Siła oddziaływania zależy w znacznym stopniu od dojrzałości i integralności jego osobowości. Wiele struktur religijnych powstało i powstaje nadal, aby realizować zadania przekazywania doktryny wiary, jej pogłębiania i podtrzymywania. Świadomość obecności i działania Transcendencji w życiu ludzi znajduje wyraz także w innych strukturach religijnych: są to różnego rodzaju ruchy religijne, kościoły i ich instytucje, grupy, organizacje i stowarzyszenia inspirowane religią. Człowiek, dla którego rzeczywistym priorytetem jest troska transcendentna, oddziałuje też na relacje interpersonalne, starając się właściwie je ukierunkować w duchu wyznawanych zasad, np. w przypadku chrześcijaństwa pierwszym zadaniem i nakazem jest wzajemna miłość. Odpowiada to praktycznemu społeczno-kulturowemu poziomowi realizacji wyznawanych prawd. 


\section{Relacje między troskami}

Relacje między troskami w życiu człowieka, jak opisuje Archer, kształtują się w procesie refleksyjności: jego wewnętrznej konwersacji. Określa on, co jest dla niego najważniejsze, dając poprzez to pierwszeństwo pewnej trosce, tworząc hierarchię, która może stopniowo ewoluować w ciągu całego jego życia lub zmienić się w jednej chwili.

Istnieją różne powiedzenia czy stwierdzenia, które w pewien sposób wyrażają tę hierarchię, takie jak: „pieniądze są najważniejsze”, „kariera jest najważniejsza”, „zdrowie jest najważniejsze”, „miłość jest najważniejsza”. W przypadku niektórych osób hierarchia wartości, a w konsekwencji i trosk nie jest dobrze ugruntowana. Hierarchia wartości pociąga za sobą szczególną konfigurację trosk w życiu każdego człowieka. Wynika z tego, że istnieje wiele różnych konfiguracji: czasami jedna z trosk ma charakter dominujący, czasami są na podobnym poziomie, czasami, w przypadku braku głębszej refleksji, istnieje pewien chaotyczny ich układ.

\section{Schemat 1. Układ trosk bez określonej hierarchii ważności}
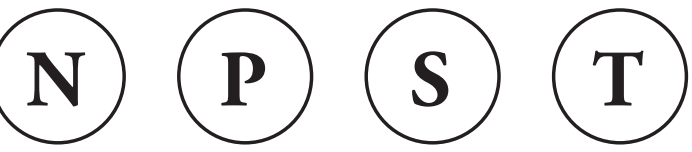

Źródło: opracowanie własne.

Nie jest celem tego krótkiego opracowania omówienie wszystkich wzajemnych konfiguracji ludzkich trosk, dlatego przedstawione zostaną tylko dwie zasadniczo różne możliwości tych konfiguracji w odniesieniu do troski transcendentnej. Pierwszy układ przedstawia osobę o słabej wierze, a nawet osobę bez wiary: troska transcendentna istnieje, ale jest mniej ważna i podporządkowana innym. U niektórych ludzi ma ona wymiar „szczątkowy”, zwykle związany z odniesieniem do końca ich życia.

Schemat 2. Układ trosk, w którym troska transcendentna jest niedowartościowana

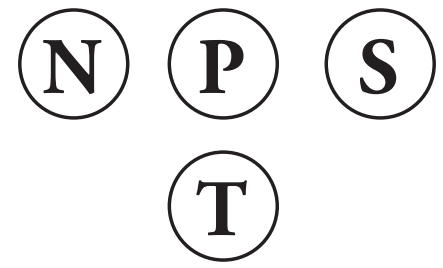

Źródło: opracowanie własne.

W tym przypadku zdrowie, pozycja społeczna czy własne dokonania mają większe znaczenie dla osoby niż zainteresowanie rzeczywistością transcendentną, niezależnie od tego, co ostatecznie uznaje ona za najważniejsze. Pominięte zostaną zatem różne możliwe w tym względzie kombinacje. Natomiast druga z rozważanych konfiguracji pokazuje sytuację, w której troska transcendentna podporządkowuje sobie wszystkie pozostałe troski: często jest tak w przypadku osób w różnych grupach religijnych, ale może to też być przypadek osoby, która nie identyfikuje się z żadną istniejącą tradycją religijną.

\section{Schemat 3. Układ trosk, w którym troska transcendentna jest najważniejsza}

Źródło: opracowanie własne.

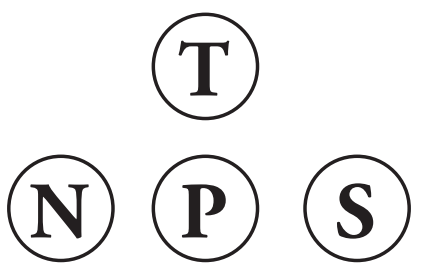


Taki układ trosk oznacza, że człowiek, stając niekiedy przed koniecznością wyboru między wartościami, jest zdolny dla realizacji troski transcendentnej poświęcić swoje siły i zdrowie, zrezygnować z dalszego rozwoju własnych kompetencji, narazić czy nawet utracić pozycję społeczną (wiara ważniejsza niż pieniądze czy kariera), poświęcić swoje życie dla innych (np. opieka nad chorymi motywowana religijnie) czy nawet ostatecznie oddać swoje życie za drugiego człowieka (z motywów religijnych) czy jedynie za wyznawaną wiarę, będąc prześladowanym. Przyjęcie takiego układu troski transcendentnej wobec innych trosk oznacza również najczęściej zaakceptowanie odpowiedniego uporządkowania pozostałych trosk względem siebie, co wypływa z nauczania poszczególnych religii, np. zdrowie jest ważniejsze od pieniędzy czy miłość do drugiego człowieka ważniejsza niż kariera.

W ciągu życia człowieka dokonuje się ewolucja relacji między troskami, która wiąże się z rozwojem człowieka i zmieniającymi się okolicznościami życia. Jest to dynamiczny proces, w którym transcendentne nakierowanie może zyskać na znaczeniu (wraz z wiekiem, chorobą czy np. przeżytą traumą), ale niekoniecznie. Zależy to od wielu różnych czynników. Jednym z istotnych jest oddziaływanie osób, dla których troska ta jest najważniejsza i którze pobudzają refleksję u innych osób na ten temat. W przypadku niektórych osób można zaobserwować pewien „zwrot transcendentny”, tzn. nagłą zmianę postawy na wyrażającą dążenie w kierunku Transcendencji, choć często była ona przygotowana przez wcześniejsze doświadczenia i przemyślenia (wewnętrzna konwersacja), które dotychczas nie znajdowały odbicia w ich słowach i działaniach. Łączyć się to może ze zmianą rozumienia Transcendencji i jej relacji wobec człowieka, np. już nie jako przeciwieństwa budowania dobra doczesnego czy zagrożenia dla dobra człowieka ani ograniczenia jego wolności, ale jako ostateczne źródło jego dobra.

\section{Podsumowanie}

Dominująca rola troski transcendentnej w życiu wielu ludzi stanowi ważną wskazówkę do zaliczenia jej do zbioru najważniejszych czy podstawowych trosk. To włączenie i wskazanie na znaczenie rzeczywistości transcendentnej wydaje się ważne dla właściwego postrzegania kondycji człowieka i społecznej rzeczywistości. W przeciwnym razie nie można ostatecznie zrozumieć tych rzeczywistości, gdyż świadomie zostaje wykluczony ważny element kształtowania człowieka i zmian społecznych. Obraz człowieka staje się niepełny czy wręcz zniekształcony, a w łańcuchu zmian społecznych brakuje istotnych elementów przyczynowych (co wypływa już z rozważań Margaret S. Archer).

Przejawem uniwersalnego znaczenia troski transcendentnej jest powszechna obecność wytworów związanych z transcendencją w całej kulturze, której nie da się ani zaprzeczyć, ani wymazać. Nieuwzględnienie jej tylko dlatego, że istnieje część ludzi, która deklaruje się jako niewierzący - ateiści, nie jest wystarczającym powodem. Z jednej strony bowiem to, co odrzucają, jest często jedynie konkretną wizją Transcendencji, którą przedstawiają poszczególne religie, czy może lepiej obrazem tej Transcendencji, który pod wpływem danej religii wytworzyli. Po wtóre, jeśli wziąć pod uwagę inne troski uznawane za podstawowe w życiu człowieka, to z łatwością można wskazać, że jest również część ludzi, która nie dba o środowisko swego życia, zdrowie, kompetencje i umiejętności, pozycję społeczną czy o dobro innych.

W końcu, jeśli uwzględnione zostanie w pełni omówione w tekście rozumienie troski transcendentnej, to należy stwierdzić, że dotyczy ona każdego człowieka przynajmniej w pewnym zakresie, a zatem ma rzeczywiście również charakter uniwersalny. Jeśli nie każdy wyznaje wiarę w jakiegoś boga, to każdy musi stanąć wobec zagadnienia śmierci, wobec kwestii życia po śmierci, a także odpowiedzieć sobie na pytanie o istnienie i charakter rzeczywistości, którą określamy jako Bóg. Jeśli chodzi o osoby religijne, którzy stanowią na świecie zdecydowaną większość, troska ta ma bardzo ważne znaczenie w całej swej rozciągłości, a często ma ona również decydujący wpływ na życie i zachowania społeczne. To wszystko uprawnia do uznania takiej troski jako troski podstawowej dla człowieka, dla całej ludzkości. 


\section{Bibliografia}

Archer M.S., Collier A., Porpora D.V. (2004a), Transcendence. Critical realism and God. London-New York: Routledge.

Archer M.S., Collier A., Porpora D.V. (2004b), What do we mean by God [w:] M.S. Archer, A. Collier, D.V. Porpora, Transcendence. Critical realism and God. London-New York: Routledge, s. 24-40.

Archer M.S. (2004a), Models of man: the admission of transcendence [w:] M.S. Archer, A. Collier, D.V. Porpora, Transcendence. Critical realism and God. London-New York: Routledge, s. 63-81.

Archer M.S. (2004b), Western mysticism and the limits of language [w:] M.S. Archer, A. Collier, D.V. Porpora, Transcendence. Critical realism and God. London-New York: Routledge, s. 92-108.

Archer M.S. (2004c), On understanding religious experience: St Teresa as a challenge to social theory [w:] M.S. Archer, A. Collier, D.V. Porpora, Transcendence. Critical realism and God. London-New York: Routledge, s. 138-154.

Archer M.S. (2013), Człowieczeństwo. Problem sprawstwa (tłum. A. Dziuban). Kraków: Zakład Wydawniczy Nomos.

Archer M.S. (2015), The Relational Subject and the person: self, agent, and actor [w:] P. Donati, M.S. Archer, The Relational Subject. Cambridge: Cambridge University Press, s. 85-122.

Bauman Z. (1998), Śmierć i nieśmiertelność. O wielości strategii życia (tłum. N. Leśniewski). Warszawa: Wydawnictwo Naukowe PWN.

Donati P., Archer M.S. (2015), The Relational Subject. Cambridge: Cambridge University Press.

Glaser B G., Strauss A.L. (1965), Awareness of dying. Chicago: Aldine Pub. Co.

Mariański J. (2017), Umieranie i śmierć w ujęciu socjologicznym w nawiązaniu do myśli Jana Szczepańskiego [w:] D. Kadłubiec, E. Ogrodzka-Mazur, A. Kasperek (red.), W kręgu myśli Profesora Jana Szczepañskiego, t. 3. Cieszyn: Arka, s. 21-40.

Motak D. (2013), Między transcendencją a immanencją. Religia w myśli Georga Simmela. Kraków: Libron.

Pieper J. (1970), Śmierć i nieśmiertelność. Paris: Éditions du Dialogue.

Seibert U., Luther H. (2010), Your Path, the Truth and Existence after Death. Munich: Hans Luther.

Simmel G. (2007a), Filozofia życia. Cztery rozdziaty metafizyczne (tłum. M. Tokarzewska). Warszawa: IFiS PAN.

Simmel G. (2007b), Śmierć i nieśmiertelność [w:] tegoż, Filozofia życia. Cztery rozdziaty metafizyczne (tłum. M. Tokarzewska). Warszawa: IFiS PAN, s. 90-132.

Simmel G. (2007c), Transcendencja życia [w:] tegoż, Filozofia życia. Cztery rozdziaty metafizyczne (tłum. M. Tokarzewska). Warszawa: IFiS PAN, s. 15-35.

Szczepański J. (1995), Wizje naszego życia. Warszawa: Wydawnictwo Prywatnej Wyższej Szkoły Businessu i Administracji.

Szczepański J. (1999), Fantazje na temat czasu. Lublin: KUL.

Sztompka P. (2005), Socjologia zmian spotecznych. Kraków: Znak.

Wysocki A. (2015), Transcendencja w ujęciu Margaret S. Archer. „Uniwersyteckie Czasopismo Socjologiczne” 10(1), s. 130-153. 